\title{
Psychological Impact of the Corona Virus Lockdown on the General Population: A Cross Sectional Online Survey
}

\author{
Vikas Gaur ${ }^{1}$, Akhilesh Jain², Gaurav Purohit ${ }^{1}$, Kiran Gaur ${ }^{3}$ \\ ${ }^{1}$ Mahatma Gandhi Medical College and Hospital, Jaipur, India, ${ }^{2}$ Department of Psychiatry, \\ ESIC Model Hospital, Jaipur, India, ${ }^{3}$ Department of Statistics SKNCOA, Jobner, India
}

\begin{abstract}
Purpose: To assess the psychological impact of COVID-19 infection lockdown on the general population. Methods: From $28^{\text {th }}$ April to $4^{\text {th }}$ May 2020, an online survey was conducted using snowballing sampling and invitation through online social media to participate. Socio-demographic and clinical variables were collected. Psychological impact was assessed with the help of self designed questionnaire adapted from DSM-5 Self-Rated Level 1 CCSM-Adult scale. Results: In total, there were 568 responses from different cities / villages of the country. Out of these eight responses were excluded from the study because of lack of consent and final sample size analyzed was 560 (358 male, 202 female). Half of the participants were under 35 years of age, $63.9 \%$ were male, $49 \%$ have done post graduation and $59.1 \%$ were living in nuclear family. Analysis of response revealed presence of a high prevalence of psychiatric symptoms ranging from $5.5 \%$ to $49.3 \%$ in the participants. Anxiety symptoms (49.3\%), manic symptoms (37.3\%) depressive symptoms (36.1\%), anger issues $(28.6 \%)$, somatic symptoms (26.3\%) and sleep problems (24.5\%) were the most common domains of psychiatric symptomatology reported by participants. Conclusion: Our study provides early evidence of a significant psychological impact of COVID-19 infection and lockdown on common people living in the community indicating a need for quick, comprehensive and longitudinal assessment of mental health needs of the population for early diagnosis and prevention of psychiatric disorders.
\end{abstract}

Key words: COVID-19; corona virus; lockdown; mental health; impact; psychological; psychiatric symptoms

Copyright $@ 2021$ KBCSM, Zagreb

e-mail: apr.kbcsm@gmail.com•www.http://apr.kbcsm.hr

\section{Introduction}

COVID 19 is a disease caused by Novel Corona virus. First case of corona virus was detected in wet market of Wuhan in Hubei Province of China in December 2019 after that on 30 January 2020, India reported its first

Correspondence to: Dr. Vikas Gaur, PhD

Department of Psychiatry, Mahatma Gandhi Medical College and Hospital, Jaipur, Rajasthan, India

Phone: + 919829158478

E-mail: drvikasgaur@gmail.com case in Kerala. On 11 March 2020, WHO declared COVID 19 as pandemic [1,2].

When COVID-19 cases started rising in India, in an attempt to stop the spread of virus, Government of India declared nationwide Lockdown on $25^{\text {st }}$ of March for 21 days. On $14^{\text {th }}$ of April it was further extended for 19 more days till $3^{\text {rd }}$ of May 2020 restricting people completely from stepping out of their homes (Gettleman J, Schultz K and Modi, 2020; BBC News, 2020) [3,4]. Current lockdown by India is the biggest lockdown in history of humankind [5]. 
Pandemic such as COVID-19 can themselves cause significant psychological distress and symptoms of mental illness [6]. Although considered to be an important decision to stop the virus spread, there are likely to be several unsolved issues related to the impact of lockdown such as limitation of movement, inability to maintain healthy lifestyle, restrictions on the availability of important medicines and other daily needs, consulting doctors when required. All these factors can significantly increase the stress level and its associated impact on normal well being [6].

General public globally in the COVID-19 era is undergoing severe psychological pressure which may also lead to various psychological problems, such as anxiety, fear, depression, and insomnia [7].

Unlike other western countries, India has comparatively, experienced lesser impact of COVID19 but still due to lockdown and prevailing COVID-19 situation, most people throughout the country are apparently experiencing fear and uncertainty about the future. It has been estimated that there will be a significant increase in anxiety, depression, irritability and substance use disorder among general population because of inevitability of loneliness and its squeal as people are confined in their homes or wherever they are [8].

In current scenario, very limited literature is available related to psychological impact of COVID- 19 outbreak and the resultant lockdown and there is even paucity of research specifically related to effect of lockdown due to COVID-19 on mental health of general population [9].

When whole world is fighting this deadly viral illness, focus on the issues related to psychological impact of COVID-19 lockdown should not be compromised. In the absence of sufficient data and published literature on this issue, it is too early to predict what impact this lockdown can have on the mental health of people living in the community. To address the current gap in literature, the present study was undertaken.

\section{Subjects and Methods}

This study was conducted by Department of Psychiatry of a tertiary care hospital attached to a medical college in Jaipur and was duly approved by Institutional Ethics Committee.

A cross-sectional web-based survey design was used to assess the psychological impact of corona virus infection and Lockdown. Snowball sampling strategy was used to recruit the participant. Sample size was not predetermined and it was decided to include all the participants who are willing to give consent for participating in the study during the pre decided time period of 7 days. The period of data collection was from $28^{\text {th }}$ of April to $4^{\text {th }}$ of May 2020, the day on which the lockdown was supposed to end.

Data was collected using an online survey platform (Google Form) developed by Google) which is cloud-based tool used for designing and developing online questionnaires and is a obvious choice for web based survey in Indian setting [10].

Potential participants were invited through Whatsapp messages as well as mobile text message with an embedded link, which on clicking by the recipient lead them to an online Google Form. The respondents were also encouraged to invite their family members, friends to take part in the survey by forwarding the invitation to participate in the study. Data was collected anonymously and all respondents provided written consent for participating in the study. Survey was circulated among approximately 1600 people. Only those participants who were willing to give consent for the study were included in the study. There were 568 responses from different cities / villages of the country. Out of these eight responses were excluded from the study because of missing data and final sample size analyzed was 560 (358 male, 202 female).

\section{Subjects}

A specially designed web-based Google Form was created for the study. Once the users clicked 
the link given in Whatsapp chat text or SMS message, a Google Form having information about the nature and purpose of study was opened directly leading the participants to the information regarding the study followed by consent to participate. On giving consent and agreeing to participate, participants were taken to next part of survey containing questions related to socio-demographic information and past history of any medical or psychiatric illness / substance dependence.

Second part of survey consisted of questions regarding psychiatric symptomatology which were adapted from DSM-5 Self-Rated Level 1 Cross-Cutting Symptom Measure (CCSM), developed by American Psychiatric Association [11]. CSSM consists of 23 questions in a selfreport format that evaluates mental health domains such as depression, anger, mania, anxiety, somatic symptoms, suicidal ideation, psychosis, sleep problems, memory, repetitive thoughts and behaviors, dissociation, personality functioning, and substance use using a 5-point likert scale. Consistently high scores on a particular domain may indicate significant and problematic symptoms for the individual that might warrant further assessment, treatment, and follow-up. Additional inquiry is based on the highest score on any item within a domain, the clinician is asked to indicate that score in the "Highest Domain Score" column. A rating of mild (i.e., 2) or greater on any item within a domain (except for substance use, suicidal ideation, and psychosis) may serve as a guide for additional inquiry and follow up to determine if a more detailed assessment for that domain is necessary. This scale has a good testretest for using in research and clinical settings (Cronbach's alpha $=0.90)$ [12].

All factors used in the self designed survey questionnaire were identical to the original CCSM instrument except for Personality functioning factor which was not included in the questionnaire. Only one reminder was sent to all the contacts that were circulated the survey and total anonymity was maintained. Respondents could fill the survey through the predesigned questionnaire only once. All questions were mandatory in the survey.

\section{Statistical analysis}

Descriptive statistics were conducted for the socio-demographic variable and clinical parameters (like physical symptoms and contact history). Chi Square test and cross tabulation was used to draw meaningful conclusion. Statistical analysis was performed using SPSS Statistic 22.0.

\section{Results}

As shown in Table 1, the sample which included 560 participants from around 70 cities / Villages in the country consist of $64 \%$ male. Most common age group was 18-24 years $(29.5 \%)$ followed closely by $35-44$ years (26.1\%) and $25-34$ years (20.7\%). About $58 \%$ of participants were working, 31\% were student and the remainder of the sample was unemployed or retired. Regarding the level of education, about $49.6 \%$ of participants were postgraduate, $39.6 \%$ graduate and $10.7 \%$ studied until their $12^{\text {th }}$ class. About $59 \%$ were living in nuclear family, 60\% were married and 59\% have monthly family income of INR 47438 per month or more. About $15 \%$ of participants have a previous history of chronic medical illness and 6\% reported having a history of psychiatric illness in past.

As shown in Table 2 and Figure 1, very high magnitudes of psychiatric symptomatology were reported by the participants. Anxiety symptoms were the most common domain of psychiatric symptomatology $(49.3 \%)$ reported followed by mania $(37.3 \%)$ depression (36.1\%), anger issues (28.6\%), somatic symptoms $(26.3 \%)$, repetitive thoughts and Behavior $(26.1 \%)$ and insomnia $(24.5 \%)$. Other frequently reported symptoms were memory disturbance $(12.7 \%)$, Psychosis (9.3\%), and Dissociation $(6.7 \%)$. A high rate of substance abuse $(9.6 \%)$ was also reported. It was also concerning that $5.5 \%$ of the participants acknowledged items on the suicidal ideation domain.

As shown in Table 3, relationships between mental health domain and socio-demographic 
Table 1. Sociodemographic distribution

\begin{tabular}{lr}
\hline Variable & $\mathrm{n}=560 \mathrm{f}(\%)$ \\
\hline Sex & $358(63.9)$ \\
Male & $202(36.1)$ \\
Female & \\
\hline Age group & $165(29.5)$ \\
$18-24$ & $116(20.7)$ \\
$25-34$ & $146(26.1)$ \\
$35-44$ & $90(16.1)$ \\
$45-54$ & $25(4.5)$ \\
$55-64$ & $18(3.2)$ \\
$\geq 65$ & \\
\hline Occupation & $28(5)$ \\
House wife & $110(19.6)$ \\
Government. job & $174(31.1)$ \\
Student & $124(22.1)$ \\
Private job & $21(3.8)$ \\
Retired person & $19(3.4)$ \\
Unemployed & $222(12.5)$ \\
Self employed & $278(49.6)$ \\
\hline Other job & \\
Education & \\
Graduate & \\
\hline & \\
\hline & \\
Post graduate & \\
\hline
\end{tabular}

variables were further analyzed using Cross tabulation and Chi Square Test.

Depression Domain: Significant association was observed between depressive symptoms, marital status and family income as divorced and unmarried participants and participants with low family income were more depressed in comparison to married participants and those with high family income.

Anger Domain: Participants belonging to younger age group (18-44 years), of female gender, as well as the unmarried participants reported being angry or irritable more than usual in past 1 month in comparison to other participants.
Table 1. (Continued)

\begin{tabular}{lr}
\hline Variable & $\mathrm{n}=560 \mathrm{f}(\%)$ \\
\hline Type of family & $331(59.1)$ \\
Nuclear family & $229(40.9)$ \\
Joint family & \\
\hline Relationship status & $339(60.5)$ \\
Married & $210(37.5)$ \\
Unmarried & $2(0.35)$ \\
Divorced & $9(1.6)$ \\
Widow & \\
\hline Family income (INR) & $32(5.7)$ \\
$<2390$ & $11(2.0)$ \\
$2391-7101$ & $13(2.3)$ \\
$7102-11836$ & $35(6.3)$ \\
$11837-17755$ & $26(4.6)$ \\
$17756-23674$ & $113(20.2)$ \\
$23674-47437$ & $330(58.9)$ \\
47438 and above & \\
\hline Past medical history & $86(15.4)$ \\
Yes & $474(84.6)$ \\
No & $34(6.1)$ \\
\hline Past psychiatric history & $526(93.9)$ \\
Yes &
\end{tabular}

Mania Domain: Interestingly, participants belonging to the age groups from 45 years onward, those married and self-employed, reported feeling full of energy even after sleeping very less when compared to other groups.

Anxiety Domain: 276 (49.3\%) participants reported anxiety symptoms reflecting high prevalence of anxiety symptoms in the study group; however, socio-demographic variables like age, sex, marital status, education, occupation, family income showed no significant association with anxiety.

Somatic symptoms Domain: In comparison to married participants, unmarried / widow / widower status participants were experi- 
Table 2. Psychiatric symptomatology (domain)

\begin{tabular}{clr}
$\begin{array}{c}\text { Domain } \\
\text { Number }\end{array}$ & \multicolumn{1}{c}{ Domain } & $\begin{array}{c}\text { Number } \\
=\mathrm{n}(\%)\end{array}$ \\
\hline 1 & Depression & $202(36.1)$ \\
2 & Anger & $160(28.6)$ \\
3 & Mania & $209(37.3)$ \\
4 & Anxiety & $276(49.3)$ \\
5 & Somatic symptoms & $147(26.3)$ \\
6 & Suicidal ideation & $31(5.5)$ \\
7 & Psychosis & $52(9.3)$ \\
8 & Sleep problems & $137(24.5)$ \\
9 & Memory & $71(12.7)$ \\
10 & Repetitive thoughts and & $146(26.1)$ \\
& behavior & $37(6.6)$ \\
11 & Dissociation & $54(9.6)$ \\
\hline
\end{tabular}

encing significant unexplained aches and pain and also felt that their illnesses are not being taken seriously enough.

Suicidal Ideation domain: 31 (5.5\%) of participants admitted having thoughts of selfharm during the past one-month period. Majority of them were students, followed by participants in government and private jobs.

Psychosis Domain: No significant association was observed between psychosis domain and socio-demographic variables.

Sleep problems Domain: Unmarried participants were experiencing significantly more sleeping difficulty in comparison to married participants.

Memory domain: Memory impairment was most visible in those who were unemployed, students or unmarried.

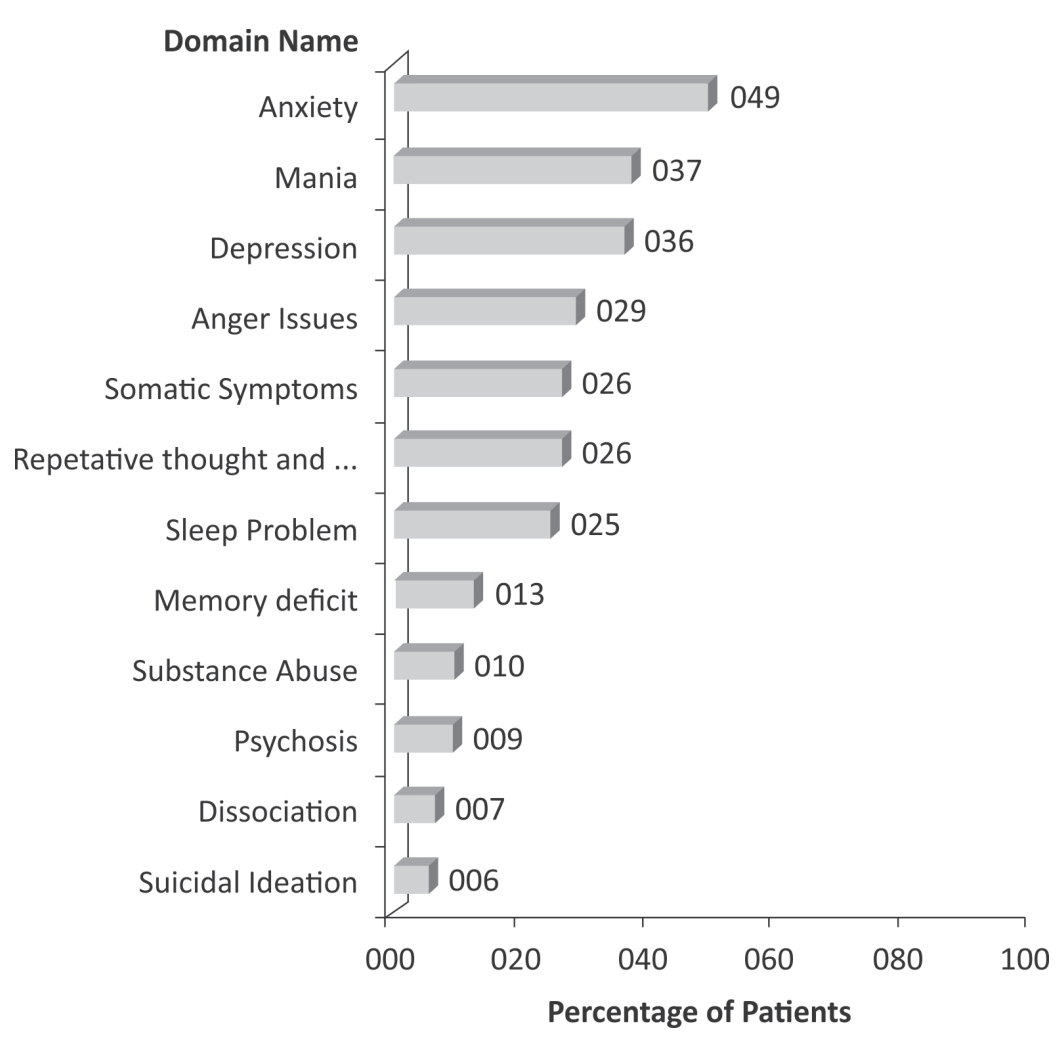

Figure 1. Psychiatric symptomatology (domain) 
Table 3. Association of demographic variables and impact on psychological health

\begin{tabular}{|c|c|c|c|c|c|c|c|c|}
\hline \multirow[t]{2}{*}{$\begin{array}{l}\text { Domain } \\
\text { Number }\end{array}$} & \multirow[t]{2}{*}{ Domain } & \multicolumn{7}{|c|}{ Chi-square (P-value) } \\
\hline & & Age & Sex & Occupation & Education & $\begin{array}{c}\text { Family } \\
\text { structure }\end{array}$ & $\begin{array}{l}\text { Marital } \\
\text { Status }\end{array}$ & $\begin{array}{l}\text { Family } \\
\text { Income }\end{array}$ \\
\hline 1 & Depression & $\begin{array}{c}8.64 \\
(0.12)\end{array}$ & $\begin{array}{c}1.93 \\
(0.16)\end{array}$ & $\begin{array}{c}9.97 \\
(0.62)\end{array}$ & $\begin{array}{c}2.19 \\
(0.33)\end{array}$ & $\begin{array}{c}0.84 \\
(0.35)\end{array}$ & $\begin{array}{l}9.24^{*} \\
(0.02)\end{array}$ & $\begin{array}{c}12.89^{*} \\
(0.04)\end{array}$ \\
\hline 2 & Anger & $\begin{array}{c}23.12^{* *} \\
(0.00)\end{array}$ & $\begin{array}{l}5.72 * * \\
(0.01)\end{array}$ & $\begin{array}{l}18.65 \\
(0.13)\end{array}$ & $\begin{array}{c}4.75 \\
(0.09)\end{array}$ & $\begin{array}{c}0.12 \\
(0.91)\end{array}$ & $\begin{array}{c}11.48^{* *} \\
(0.01)\end{array}$ & $\begin{array}{l}10.47 \\
(0.10)\end{array}$ \\
\hline 3 & Mania & $\begin{array}{c}25.64^{* *} \\
(0.00)\end{array}$ & $\begin{array}{c}1.08 \\
(0.29)\end{array}$ & $\begin{array}{c}27.45^{* *} \\
(0.01)\end{array}$ & $\begin{array}{c}2.19 \\
(0.33)\end{array}$ & $\begin{array}{c}2.01 \\
(0.15)\end{array}$ & $\begin{array}{c}14.20 * * \\
(0.00)\end{array}$ & $\begin{array}{c}5.48 \\
(0.48)\end{array}$ \\
\hline 4 & Anxiety & $\begin{array}{c}1.00 \\
(0.96)\end{array}$ & $\begin{array}{c}2.30 \\
(0.12)\end{array}$ & $\begin{array}{c}9.81 \\
(0.70)\end{array}$ & $\begin{array}{c}2.01 \\
(0.36)\end{array}$ & $\begin{array}{c}3.06 \\
(0.08)\end{array}$ & $\begin{array}{c}3.52 \\
(0.32)\end{array}$ & $\begin{array}{c}6.86 \\
(0.33)\end{array}$ \\
\hline 5 & $\begin{array}{l}\text { Somatic } \\
\text { symptoms }\end{array}$ & $\begin{array}{c}5.74 \\
(0.33)\end{array}$ & $\begin{array}{c}3.43 \\
(0.06)\end{array}$ & $\begin{array}{l}15.49 \\
(0.27)\end{array}$ & $\begin{array}{c}4.38 \\
(0.11)\end{array}$ & $\begin{array}{c}2.33 \\
(0.12)\end{array}$ & $\begin{array}{c}14.47^{* *} \\
(0.00)\end{array}$ & $\begin{array}{c}3.14 \\
(0.79)\end{array}$ \\
\hline 6 & $\begin{array}{l}\text { Suicidal } \\
\text { ideation }\end{array}$ & $\begin{array}{c}8.86 \\
(0.11)\end{array}$ & $\begin{array}{c}1.52 \\
(0.22)\end{array}$ & $\begin{array}{c}24.29 * \\
(0.02)\end{array}$ & $\begin{array}{c}3.36 \\
(0.18)\end{array}$ & $\begin{array}{c}0.07 \\
(0.78)\end{array}$ & $\begin{array}{c}3.00 \\
(0.39)\end{array}$ & $\begin{array}{c}3.95 \\
(0.68)\end{array}$ \\
\hline 7 & Psychosis & $\begin{array}{c}2.67 \\
(0.75)\end{array}$ & $\begin{array}{c}2.75 \\
(0.09)\end{array}$ & $\begin{array}{l}17.37 \\
(0.18)\end{array}$ & $\begin{array}{c}1.77 \\
(0.411)\end{array}$ & $\begin{array}{c}0.32 \\
(0.57)\end{array}$ & $\begin{array}{c}2.22 \\
(0.52)\end{array}$ & $\begin{array}{c}9.67 \\
(0.13)\end{array}$ \\
\hline 8 & $\begin{array}{l}\text { Sleep } \\
\text { problems }\end{array}$ & $\begin{array}{c}2.65 \\
(0.75)\end{array}$ & $\begin{array}{c}1.03 \\
(0.30)\end{array}$ & $\begin{array}{l}16.58 \\
(0.21)\end{array}$ & $\begin{array}{c}3.10 \\
(0.21)\end{array}$ & $\begin{array}{c}0.03 \\
(0.84)\end{array}$ & $\begin{array}{l}8.74 * \\
(0.03)\end{array}$ & $\begin{array}{c}6.30 \\
(0.39)\end{array}$ \\
\hline 9 & Memory & $\begin{array}{c}7.92 \\
(0.16)\end{array}$ & $\begin{array}{c}0.03 \\
(0.85)\end{array}$ & $\begin{array}{c}28.98^{* *} \\
(0.00)\end{array}$ & $\begin{array}{c}1.59 \\
(0.45)\end{array}$ & $\begin{array}{c}0.91 \\
(0.33)\end{array}$ & $\begin{array}{c}12.63^{* *} \\
(0.00)\end{array}$ & $\begin{array}{c}9.44 \\
(0.15)\end{array}$ \\
\hline 10 & $\begin{array}{l}\text { Repetitive } \\
\text { thoughts and } \\
\text { behavior }\end{array}$ & $\begin{array}{l}10.25 \\
(0.06)\end{array}$ & $\begin{array}{c}5.97 * * \\
(0.01)\end{array}$ & $\begin{array}{c}22.59 * \\
(0.04)\end{array}$ & $\begin{array}{c}0.11 \\
(0.94)\end{array}$ & $\begin{array}{c}0.57 \\
(0.45)\end{array}$ & $\begin{array}{c}15.55^{* *} \\
(0.00)\end{array}$ & $\begin{array}{c}2.50 \\
(0.86)\end{array}$ \\
\hline 11 & Dissociation & $\begin{array}{c}12.19^{*} \\
(0.03)\end{array}$ & $\begin{array}{c}0.88 \\
(0.34)\end{array}$ & $\begin{array}{c}26.31 * * \\
(0.01)\end{array}$ & $\begin{array}{c}3.15 \\
(0.20)\end{array}$ & $\begin{array}{c}0.09 \\
(0.76)\end{array}$ & $\begin{array}{c}17.99 * * \\
(0.00)\end{array}$ & $\begin{array}{c}30.46^{* *} \\
(0.00)\end{array}$ \\
\hline 12 & Substance Use & $\begin{array}{c}2.24 \\
(0.81)\end{array}$ & $\begin{array}{c}0.04 \\
(0.82)\end{array}$ & $\begin{array}{l}14.26 \\
(0.35)\end{array}$ & $\begin{array}{c}0.43 \\
(0.80)\end{array}$ & $\begin{array}{c}0.01 \\
(0.92)\end{array}$ & $\begin{array}{c}6.25 \\
(0.10)\end{array}$ & $\begin{array}{c}14.35^{*} \\
(0.02)\end{array}$ \\
\hline
\end{tabular}

*Significant at $5 \%$ level of Significance, ** Significant at $1 \%$ level of significance

Repetitive thoughts and behavior domain: Symptoms of repetitive thoughts and behavior were more visible in female participants, students and unmarried person.

Dissociation Domain: Participants belonging to younger age group (16-24 years), unemployed and retired participants were experiencing significantly more dissociative symptom when compared to other participants.
Substance Use Domain: Substance abuse was most visible in participants with low monthly family income.

\section{Discussion}

This study was designed to assess the psychological impact of a total lockdown due to COVID-19 in general population and is likely to be among the first such study in this regard 
in Indian scenario. Our study is unique in a sense that even though it was an online survey, our survey questionnaire was adapted from a valid instrument (DSM-5 Self-Rated Level 1 Cross-Cutting Symptom Measure) used to asses 13 psychiatric domains and identify individuals that might warrant further assessment, treatment, and follow-up.

According to literature, overall prevalence of mental disorders in India is $14.3 \%$. Both Depressive Disorder and Anxiety Disorder have an overall prevalence of $3.3 \%$, respectively. Prevalence of Bipolar disorder and Schizophrenia is $0.6 \%$ and $0.3 \%$ respectively [13]. Lifetime prevalence of OCD in India is $0.6 \%$ [14].

A very interesting finding of this study was a sharp increase in psychiatric symptology reported by the participants. Corona virus infection and the prolonged lockdown appears to have affected the mental health of adult people in a very significant manner across all age groups because even though, only 34 (6.1\%) of the participants had a past history of any psychiatric disorder before the lockdown started, a high percentage of newly onset psychiatric symptoms were reported by participants ranging from 7.9 to $49.2 \%$.

According to a review article on COVID-19 and mental health, anxiety and depressive symptoms (16-28\%), self-reported stress $(8 \%)$, and insomnia are common psychological reactions to the COVID-19 pandemic [15].

In our study, anxiety, manic and depressive symptoms were reported by $49.3 \%, 37.3 \%$ and $36.1 \%$ of participants, while sleeping difficulty was reported by $24.5 \%$ of participants.

Additionally, high prevalence of other psychiatric symptoms was also observed. They could be attributed to several factors such as daily routine change, frustrations related to strict confinement at home, fear of losing job, fear of getting an infection, apparent loss in business, etc.

Psychological Impact of the Lockdown on the General Population
Approximately more than one - quarter of participants reported feeling more irritated, grouchy or angry than usual and were experiencing repetitive thoughts and behavior. About $12.7 \%$ of participants were finding difficulty in learning new information or recollecting old information. About $9.3 \%$ of participants were hearing voices when no one was around or feeling that others can hear their thought. It was also alarming that about $5.5 \%$ of participants acknowledged experiencing thoughts of actually hurting themselves. A comparatively high rate of substance abuse $(9.6 \%)$ was reported which upon further analysis was found to be related to self medication for sleeping difficultly.

No significant association was observed between depressive and anxiety symptoms with several socio-demogrpahic variables such as age, gender, occupation, education, marital status etc, suggesting that both men and women of all ages were equally affected by the corona virus lockdown and its further implications. Participants having a low family income were more depressed in comparison to other participants and this could be because of joblessness and uncertainty about future.

In a traditional Indian family, female participants tend to assume a central care giving role and are also managing the household work at the same time. In our study female participants reported feeling angrier and more irritable than usual and were experiencing repetitive thoughts which could be due to work overload, helplessness, financial uncertainty, and fear of loved ones getting infected.

Living with family, partner or relatives could act as social support and help in lowering stress during the lockdown. Individuals who are unmarried, living alone, and/or unemployed might be at a higher risk of depression, anxiety, and aggression during the lockdown. Results of our study reveal that participants who were unmarried and/or unemployed reported being more depressed, 
angrier, and were also experiencing sleeping difficulties, memory impairment and multiple somatic symptoms.

Level of education and living in a joint or nuclear family had no significant impact on the psychiatric symptomatology and no significant association of psychotic and anxiety symptoms were found with any socio-demographic variable in our study.

While the findings of this current study are based on an online survey, results obtained by us are really alarming and indicate a possibility of significant rise in mental health problems in the COVID-19 lockdown era requiring early intervention and management.

Limitations: Our study has certain limitations. Although we can state that our sample is a national representative sample due to the fact that we received responses from different parts of the country, the study itself included a modest number of participants, which restricst the statistical power of the analyses. Self-reporting of the symptoms was another important limitation as there might be a discrepancy between the responses given, which could in turn lead to inaccuracies in the information reported. Another very important limitation was that we used a self designed questionnaire

\section{References}

1. World Health Organization. WHO Timeline - COVID-19. [Internet] 2020. [cited May 2, 2020]. Available from: https://www.who.int/news-room/detail/27-042020-who-timeline---covid-19

2. Reid D. India confirms its first coronavirus case. CNBC 2020. [Internet] 2020. [cited May 2, 2020]. Available from https://www.cnbc.com/2020/01/30/india-confirms-first-case-of-the-coronavirus.html

3. Gettleman J, Schultz K. Modi Orders 3-Week Total Lockdown for All 1.3 Billion Indians. The New York Times 2020. survey which was adapted and modified from a validated scale.

Conclusion: Our study provides early evidence of a significant psychological impact of COVID-19 lockdown on adults, as we observed very high rates of psychiatric symptoms in people living in the community. Our findings also highlight the urgency in making a pre-planned strategy for early identification of vulnerable persons who are at a greater risk of suffering from psychological distress under this stressful period. Early identification of susceptible persons might help in reaching these patients for a timely psychiatric intervention.

\section{Acknowledgement}

None.

\section{Conflict of Interest}

The authors declare that there are no conflicts of interest.

\section{Funding Sources}

Not applicable.
4. [Internet] 2020. [cited May 2, 2020]. Available from:https://www.nytimes.com/2020/03/24/world/ asia/india-coronavirus-lockdown.html

5. BBC News. PM Narendra Modi says India will extend coronavirus lockdown until 3 May. [Internet] 2020. [cited May 2, 2020]. Available from: https://www.bbc. com/news/world-asia-india-52277096

6. Lancet T. India under COVID-19 lockdown. The Lancet. 2020;395:1315-1400.

7. Ghosal S, Sinha B, Majumder M, Misra A. Estimation of effects of nationwide lockdown for containing coronavirus infection on worsening of glycosylated haemoglobin and increase in diabetes-related complications: A 
simulation model using multivariate regression analysis. Diabetes Metab Syndr. 2020;14:319-323.

8. Li W, Yang Y, Liu Z-H, Zhao Y-J, Zhang Q, Zhang L, et al. Progression of Mental Health Services during the COVID-19 Outbreak in China. Int J Biol Sci. 2020;16:1732-1738.

9. Galea S, Merchant RM, Nurie N. The Mental Health Consequences of COVID-19 and Physical Distancing. [Internet] 2020 [cited May 2, 2020]. Available from. https://jamanetwork.com/journals/jamainternalmedicine/fullarticle/2764404

10. Ahmed MZ, Ahmed O, Aibao Z, Hanbin S, Siyu L, Ahmad A. Epidemic of COVID-19 in China and associated Psychological Problems. Asian J Psychiatr. 2020;51:102092.

11. Vasantha RN, Harinarayana NS. Online survey tools: A case study of Google Forms. Paper presented at the National Conference on "Scientific, Computational \& Information Research Trends in Engineering, GSSSIETW, Mysore.
12. American Psychiatric Association. Online assessment measures. [Internet] 2014. [cited May 3, 2020]. Available from: www.psychiatry.org/psychiatrists/practice/dsm/ educational-resources/assessment-measures.

13. Meaklim H, Swieca J, Junge M, Laska I, Kelly D, Joyce $\mathrm{R}$, et al. The DSM-5 Self-Rated Level 1 Cross-Cutting Symptom Measure identifies high levels of coexistent psychiatric symptomatology in patients referred for insomnia treatment. Nat Sci Sleep. 2018;10:377-383.

14. Sagar R, Dandona R, Gururaj G, Dhaliwal RS, Singh A, Ferrari A, et al. The burden of mental disorders across the states of India: the Global Burden of Disease Study 1990-2017. The Lancet Psychiatry. 2020;7:148-61.

15. Reddy YCJ, Rao NP, Khanna S. An overview of Indian research in obsessive compulsive disorder. Indian J Psychiatry. 2010;52:S200-9.

16. Rajkumar RP. COVID-19 and mental health: A review of the existing literature. Asian J Psychiatry. 20201;52:102066.

\section{Psihološki utjecaj koronavirus karantene na opću populaciju: internetsko presječno istraživanje}

Sažetak - Svrha: Procijeniti psihološki utjecaj izolacije na opću populaciju za vrijeme COVID-19 infekcije. Metode: Od 28. travnja do 4. svibnja 2020. godine provedeno je online istraživanje korištenjem uzorkovanja snježne kugle i slanjem pozivnica za sudjelovanje putem društvenih mreža. Prikupljene su socio-demografske i kliničke varijable. Psihološki utjecaj procijenjen je uz pomoć vlastitog dizajniranog upitnika prilagođenog prema DSM-5 CCSM-skali za odrasle razine 1 za samoocijenjivanje. Rezultati: Ukupno je bilo 568 odgovora iz različitih gradova/sela unutar zemlje. Osam odgovora isključeno je iz studije zbog nedostatka pristanka te je konačna analizirana veličina uzorka bila 560 (358 muških, 202 ženskih). Polovica sudionika bila je mlađa od 35 godina, 63,9\% su bili muškarci, 49\% je završilo postdiplomski studij, a $59,1 \%$ je živjelo u nuklearnoj obitelji. Analiza odgovora otkrila je prisutnost visoke prevalencije psihijatrijskih simptoma kod sudionika u rasponu od 5,5\% do 49,3\%. Simptomi anksioznosti (49,3\%), manični simptomi (37,3\%), depresivni simptomi $(36,1 \%)$, problemi s bijesom $(28,6 \%)$, somatski simptomi $(26,3 \%)$ i problemi sa spavanjem $(24,5 \%)$ bili su najčešća područja psihijatrijske simptomatologije o kojoj su izvijestili sudionici. Zaključak: Naša studija pruža rane dokaze o značajnom psihološkom utjecaju COVID-19 infekcije i karantene na obične ljude koji žive u zajednici, što ukazuje na potrebu za brzom, sveobuhvatnom i longitudinalnom procjenom potreba mentalnog zdravlja stanovništva te za ranom dijagnozom i prevencijom psihijatrijskih poremećaja.

Ključne riječi: COVID-19; koronavirus; karantena; mentalno zdravlje; utjecaj; psihološki, psihijatrijski simptomi 
